\title{
INFLUENCE OF CLASS C FLY ASH ON THE PROPERTIES OF PLASTIC CLAY AND A FIRED BRICK BODY
}

\author{
VPLIV DIMNIŠKEGA PEPELA RAZREDA C NA LASTNOSTI \\ PLASTIČNE GLINE IN ŽGANIH OPEK
}

\author{
Radomír Sokolář \\ Brno University of Technology, Faculty of Civil Engineering, Institute of Technology of Building Materials and Components, Veveří 331/95, \\ 60200 Brno, Czech Republic \\ Prejem rokopisa - received: 2019-07-12; sprejem za objavo - accepted for publication: 2019-11-04
}

doi:10.17222/mit.2019.148

\begin{abstract}
Class C fly ash (CCFA) was used, according to ASTM C618-12a, as an admixture (10\%/w) in calcareous brick clay to determine the difference (in comparison with pure clay) in the clay body plasticity (CCFA increases the water content, decreases the drying shrinkage, drying sensitivity and bulk density of a green body) and in the properties of a fired body (since CCFA acts as a pore-forming agent, we can expect a lower bulk density and better thermal insulation). Due to low firing temperatures of the brick body $\left(850^{\circ} \mathrm{C}\right.$ and $\left.1000{ }^{\circ} \mathrm{C}\right)$, there is no risk of an anhydrite decomposition as Class $\mathrm{C}$ fly ash does not increase the $\mathrm{SO}_{2}$ content in flue gas during the firing and efflorescence.

Keywords: fly ash, brick body, sulphur-dioxide emissions, firing

Avtorji so uporabili dimniški pepel razreda C (CCFA), v skladu s standardom ASTM C618-12a, kot dodatek (10 \% mas.) v karbonatno glino za opeke, da bi določili razlike, ki nastopajo v primerjavi z uporabo naravne (čiste) gline. Avtorji so pričakovali, da bo dodatek vplival tako na plastičnost surovcev (CCFA namreč poveča vsebnost vode, zmanjša skrček po sušenju, občutljivost in volumsko gostoto surovcev), kakor tudi na končno žgane opeke (sredstvo za tvorbo por namreč znižuje volumensko gostoto in poveča toplotno izolativnost). Zaradi nizkih temperatur žganja opeke $\left(850{ }^{\circ} \mathrm{C}\right.$ in $\left.1000{ }^{\circ} \mathrm{C}\right)$ ni bilo nevarnosti za razpad anhidrita, saj dodatek dimniškega pepela razreda $\mathrm{C}$ ne povečuje vsebnosti $\mathrm{SO}_{2} \mathrm{v}$ dimnih plinih med žganjem in kristalizacijo.

Ključne besede: dimniški pepel, opeka, emisije žveplovega dioksida, žganje
\end{abstract}

\section{INTRODUCTION}

Class C fly ash (CCFA, fluidized fly ash) is a by-product obtained during the combustion of a coal-limestone finely milled mixture in a fluidized-bed boiler in thermal-power or heating plants at lower temperatures (about $800{ }^{\circ} \mathrm{C}$ ). The term "fluidized fly ash" is not used in scientific literature - the type of fly ash is usually not specified. Fluidized fly ash is generally called Class C fly ash according to the American Standard ASTM C618-12a (Standard Specification of Coal Fly Ash and Raw Calcined Natural Pozzolan for Use in Concrete), which determines CCFA (Table 1).

Table 1: Classification of fly ashes according to ASTM C618-12a

\begin{tabular}{|c|c|c|c|}
\hline Class & $\Sigma\left(\mathrm{SiO}_{2}+\mathrm{Al}_{2} \mathrm{O}_{3}+\mathrm{Fe}_{2} \mathrm{O}_{3}\right)$ & $\mathrm{SO}_{3}$ & LOI \\
\hline $\mathrm{C}$ & $\min 50 \%$ & $\max 5 \%$ & $\max 6 \%$ \\
\hline
\end{tabular}

In the Czech Republic, the total production of CCFA is about 1.4 million tons per year. Fluidized technology is one of the most popular methods for burning coal and other sorts of fuel in thermal-power plants in order to limit sulphur-dioxide emissions.

*Corresponding author's e-mail:

sokolar.r@fce.vutbr.cz (Radomír Sokolář)
Fly ash/clay mixtures for the single-firing technology for dry-pressed ceramic tiles were developed experimentally, using kaolinic stoneware clay as the basic raw material and classical high-temperature fly ash., ${ }^{1,2}$ The bodies prepared with this method show a high shrinkage after firing, often even in the reduction cores, in comparison with the standard bodies based on natural-raw materials. We can use CCFA for glass-ceramic materials development. ${ }^{3,4}$ Here, CCFA shows a poorer sinterability (higher water absorption, porosity) than in ceramic bodies. ${ }^{5}$ Milling of fly-ash mixtures improves the sintering activity. ${ }^{1,6}$ The recycling of three different fly ashes (CCFAs with different $\mathrm{CaO}$ contents of 6.76-37.80\%) obtained from the coal thermal-power plants was studied for the glass materials. ${ }^{7}$

Fly ash from the coal power plant (CCFA with $14.3 \%$ of $\mathrm{CaO}$ and $3.6 \%$ of $\mathrm{SO}_{3}$ - quartz, calcite, hematite) was used for the production of bricks in the local brick factory (0-25\% of clay) as fly ash decreases the compressive strength of bricks due to a high porosity (firing at $800{ }^{\circ} \mathrm{C}$ ); as a result, a low efflorescence was observed in the bricks incorporating fly ash. ${ }^{8}$ Environmentally friendly bricks containing clay, fly ash (FA) and bottom ash (BA) were developed. An increase in the FA content leads to an increase in the apparent porosity and water absorption; however, it decreases the bulk density 
R. SOKOLÁŘ et al.: INFLUENCE OF CLASS C FLY ASH ON THE PROPERTIES OF PLASTIC CLAY ...

Table 2: Chemical compositions (in mass fractions, $w / \%$ ) of used raw materials - fly ash CCFA (Tisova) and brick clay (Novosedly)

\begin{tabular}{|c|c|c|c|c|c|c|c|c|c|c|c|}
\hline Material & $\mathrm{SiO}_{2}$ & $\mathrm{Al}_{2} \mathrm{O}_{3}$ & $\mathrm{Fe}_{2} \mathrm{O}_{3}$ & $\mathrm{TiO}_{2}$ & $\mathrm{CaO}$ & $\mathrm{MgO}$ & $\mathrm{MnO}$ & $\mathrm{K}_{2} \mathrm{O}$ & $\mathrm{Na}_{2} \mathrm{O}$ & $\mathrm{SO}_{3}$ & $\mathrm{LOI}$ \\
\hline clay & 56.4 & 12.7 & 4.4 & 0.1 & 9.8 & 3.3 & 0.1 & 3.0 & 1.7 & 0.6 & 12.2 \\
\hline CCFA & 35.0 & 23.3 & 5.5 & 5.4 & 21.5 & 1.6 & 0.1 & 0.5 & 0.1 & 2.5 & 4.5 \\
\hline
\end{tabular}

and thermal conductivity of bricks. The BA content does not have any significant influence on the properties of bricks.

All heavy metals were immobilized in the structures of fired bricks. ${ }^{9}$ Brick clay, sewage sludge and fly ash (CFFA - $2.33 \mathrm{CaO}, 0.3 \mathrm{SO}_{3}$ ) were successfully used for the production of brick fired at two different temperatures $\left(900{ }^{\circ} \mathrm{C}\right.$ and $\left.1050{ }^{\circ} \mathrm{C}\right) .{ }^{10}$ Municipal solid waste incineration (MSWI) fly ash $(36,7 \%$ of $\mathrm{CaO}$ as free $\mathrm{CaO}, \mathrm{Ca}(\mathrm{OH})_{2}$, calcite, quartz) was re-utilized for eco-friendly dry-pressed ceramic-brick production (fired at $\left.1000{ }^{\circ} \mathrm{C}\right) .{ }^{11}$ The fly ashes (CFFA $-2.26 \%$ of $\mathrm{CaO}$ and $0,03 \%$ of $\mathrm{SO}_{3}$ ) from the co-combustion of coal and pet coke were used as raw materials to replace clay to make dry-pressed fired $(800,900,1000){ }^{\circ} \mathrm{C}$ bricks. These bricks do not present environmental problems according to a leaching study. ${ }^{12}$ Dry-pressed (at $26 \mathrm{MPa}$ ) bricks based on pure-lignite fly ash with different granulometries were developed and reported in ${ }^{13}$ - their production included a compressive strength of 27-57 MPa and water absorption of 19-25\% depending on the firing temperature in a range of $900-1050{ }^{\circ} \mathrm{C}$.

The aim of the article is to define:

- The CFFA influence on the properties of a plastic and green body (interaction of brick clay and CFFA) drying sensitivity, drying shrinkage, working water.

- The effect of CFFA in a raw-material mixture used for clay masonry bricks on sulphur oxide $\mathrm{SO}_{2}$ emissions included in flue gas during the firing (up to $1000{ }^{\circ} \mathrm{C}$ and with the soaking time at $1000{ }^{\circ} \mathrm{C}$ ).

- The CFFA influence on the properties of a fired body (at $850-1000{ }^{\circ} \mathrm{C}$, the maximum firing temperatures for bricks) - water absorption, bulk density, firing shrinkage, flexural strength and efflorescence.

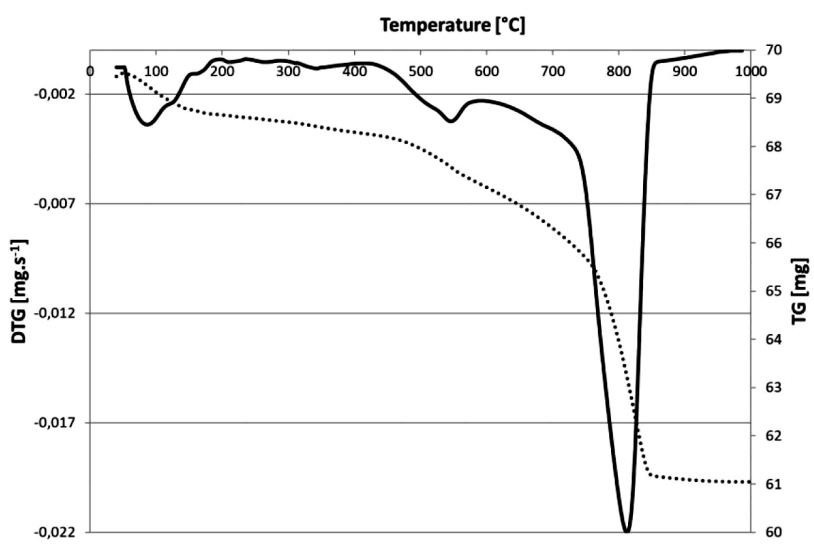

Figure 1: TG (solid line) and DTG (dashed line) of brick clay (heating at $10{ }^{\circ} \mathrm{C} / \mathrm{min}$ ). The initial mass of the sample for TG was $69.4548 \mathrm{mg}$

\section{MATERIALS, SAMPLES AND METHODS}

Fluidized fly ash CCFA from the thermal-power plant (Tisova-CEZ Group, Czech Republic) and typical brick clay for the THERM clay-masonry-unit (EN 771-1) production (Novosedly-Wienerberger Group, Czech Republic) were used for the preparation of laboratory samples. The chemical compositions of both used materials (Table 2) are typical and correspond to their mineralogical compositions (Figures 3 and 4). CFFA is characterized by a high $\mathrm{SO}_{3}$ content (in the form of anhydrite $\mathrm{CaSO}_{4}$ ), quartz, calcium oxide $\mathrm{CaO}$ and calcite $\mathrm{CaCO}_{3}$ (Table 3). Brick clay can be characterized by its calcareous nature (the content of calcite is about $12 \mathrm{w} / \%$. according to the thermal analysis - TG, DTG, Mettler Toledo TGA/DSC1 device - the decomposition of calcite in a temperature range of $720-850{ }^{\circ} \mathrm{C}$ (Figure 1), and the presence of several clay minerals (kaolinite, illite and montmorillonite), quartz and orthoclase (Figure 3). The mineralogical composition was identified using an X-ray diffraction analysis (XRD; PANALYTICAL Empyrean) with $\mathrm{Cu}-K_{\alpha}$ as the radiation source, an accelerating voltage of $45 \mathrm{kV}$, beam current of $40 \mathrm{~mA}$, diffraction angle $2 \theta$ in a range of $5-80^{\circ}$ and step scan of $0.01^{\circ}$.

Granulometry of the used materials was determined using the residue on a screen with a size of $63 \mu \mathrm{m}\left(R_{63}\right)$ (Table 3). According to granulometry (Figure 2), brick clay, suitable for the production of thermal insulating masonry THERM units (EN 771-1) was used as the basic plastic material for the preparation of test samples from the plastic body. It contains about $28 \%$ of grains below $2 \mu \mathrm{m}$ (a sedimentation analysis).

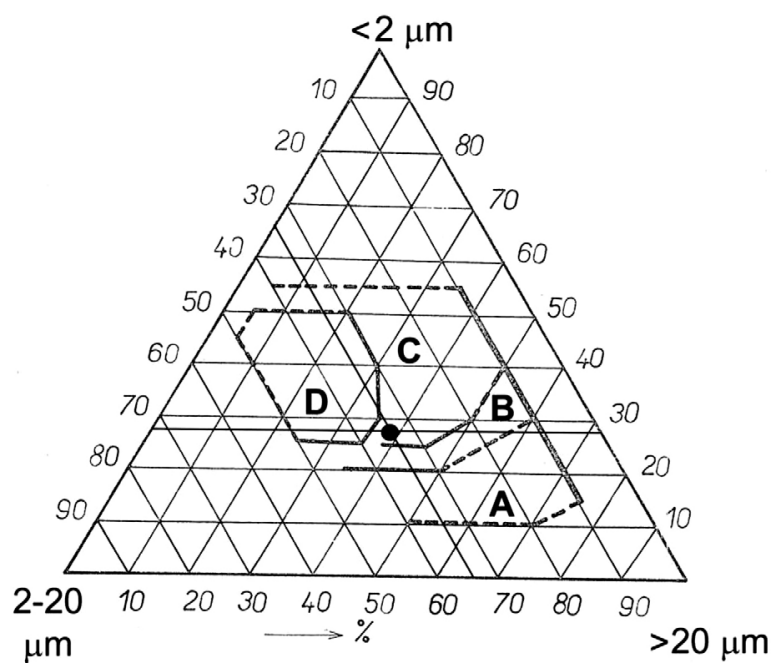

Figure 2: Grain-size classification of used brick clay (black point) according to Winkler's diagram: ${ }^{14}$ common bricks, b) vertically perforated bricks, c) roofing tiles and masonry bricks, d) hollow products 
Table 3: Residue of used fly-ash and brick-clay grains on a $63-\mu \mathrm{m}$ sieve

\begin{tabular}{|c|c|}
\hline Material & $R_{63}(w / \%)$ \\
\hline clay & 16.0 \\
\hline CCFA & 25.9 \\
\hline
\end{tabular}

For the preparation of test samples, the average sample of dried brick clay $\left(60{ }^{\circ} \mathrm{C}\right)$ was ground in a laboratory pan mill to get a homogenous fineness of $0-1 \mathrm{~mm}$. Two batches of brick clay and CCFA $(0 \% / \mathrm{w}-$ $\mathrm{N}$ and $10 \% / w-\mathrm{N} 10)$ were prepared for the experiments. The raw-material mixture (dry-milled clay and CCFA) was dry-mixed for $24 \mathrm{~h}$ in the homogenizer. The brick clay $(\mathrm{N})$ and mixture brick clay/CCFA (N10) were moistened to achieve the plasticity that corresponds to the deformation ratio of 0.7 according to K. Pfefferkorn ${ }^{15}$ $\left(H_{\mathrm{f}} / H_{0}\right.$ where $H_{0}$ is the initial height and $H_{\mathrm{f}}$ is the final height after the deformation on the Pfefferkorn apparatus). After 24-hour ageing of the plastic clay body, the samples were made by hand, the clay being churned into a metal form with dimensions of $(100 \times 50 \times 20)$ $\mathrm{mm}$.

The drying was conducted in the natural way in the laboratory at a temperature of about $21{ }^{\circ} \mathrm{C}$; the samples were subsequently finally dried in the laboratory drier at a temperature of $110{ }^{\circ} \mathrm{C}$. The established Bigot curve (Figure 5) was used to calculate the drying sensitivity index DSI-B ${ }^{16}$ :

$$
D S I-B=\frac{w_{i}-w_{\mathrm{c}}}{100} \cdot D S \quad[-]
$$

where:

$W_{i}$ is the initial water content of the plastic body during the preparation of test samples [\%];

$W_{\text {c }}$ is the critical water content of the test samples subtracted from the Bigot curve (Figure 5) (\%);

$D S$ is the drying shrinkage (\%).

The samples were fired in the laboratory electric kiln at $850{ }^{\circ} \mathrm{C}$ and $1000{ }^{\circ} \mathrm{C}\left(3{ }^{\circ} \mathrm{C} . \mathrm{min}^{-1}\right.$ with 1 -hour soaking time at the maximal temperature), which corresponds to the typical firing temperature interval for clay masonry bricks. The sulphur dioxide $\left(\mathrm{SO}_{2}\right)$ content in the flue

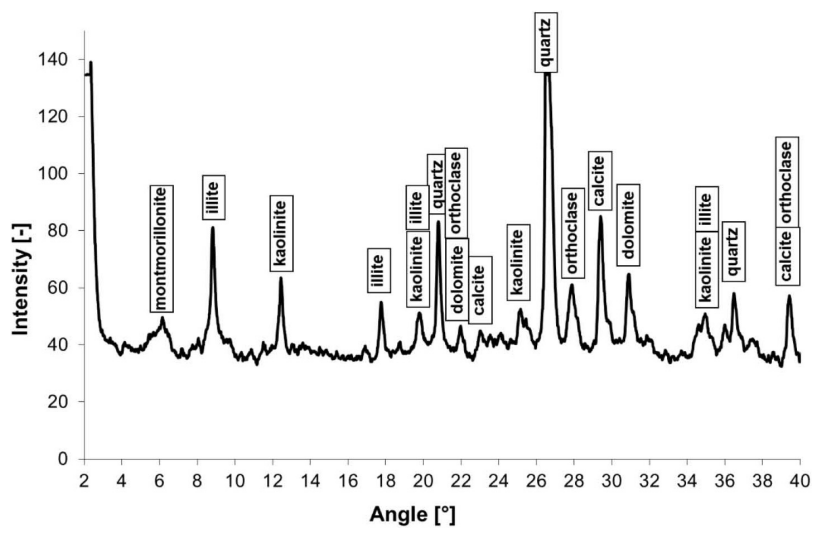

Figure 3: XRD diffraction of used brick clay

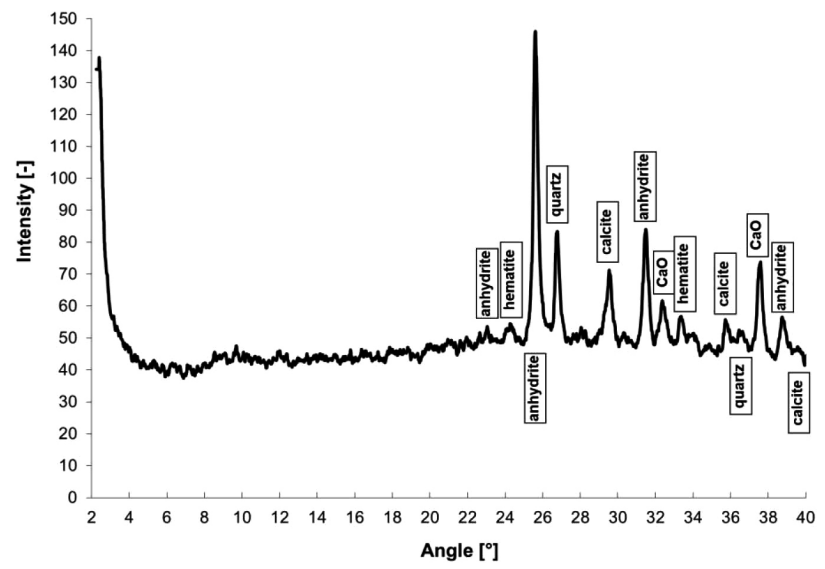

Figure 4: XRD diffraction of used CCFA

gases was assessed continually during the firing process using a TESTO 340 flue-gas analyser.

After the firing, the body properties (water absorption $W A$, bulk density $B$ and flexural strength $R$ ) were defined in accordance with the official testing standard EN ISO 10545. Firing shrinkage $F S$ was calculated with the following Equation (2):

$$
F S=\frac{\left(l_{\mathrm{f}}-l_{\mathrm{d}}\right) \cdot 100}{l_{\mathrm{d}}} \quad[\%]
$$

where:

$l_{\mathrm{d}}$ is the length of dried test samples $(\mathrm{mm})$ and $l_{\mathrm{f}}$ is the

length of fired test samples (mm).

The susceptibility to efflorescence was determined in accordance with ASTM C 67 - the test samples were immersed to a constant depth of $10 \mathrm{~mm}$ under water at one end. After $7 \mathrm{~d}$, the water was allowed to dry (at $110{ }^{\circ} \mathrm{C}$ ) in $24 \mathrm{~h}$ and observations relating to efflorescence were recorded.

\section{RESULTS AND DISCUSSION}

According to $\mathrm{K}$. Pfefferkorn, ${ }^{15} \mathrm{CCFA}$ as an additive to a raw-material mixture increases the water content $w_{\mathrm{r}}$ (Table 4), achieving the plasticity of a clay body with a ratio of 0.7 by $4.3 \%$ and, at the same time, reduces the

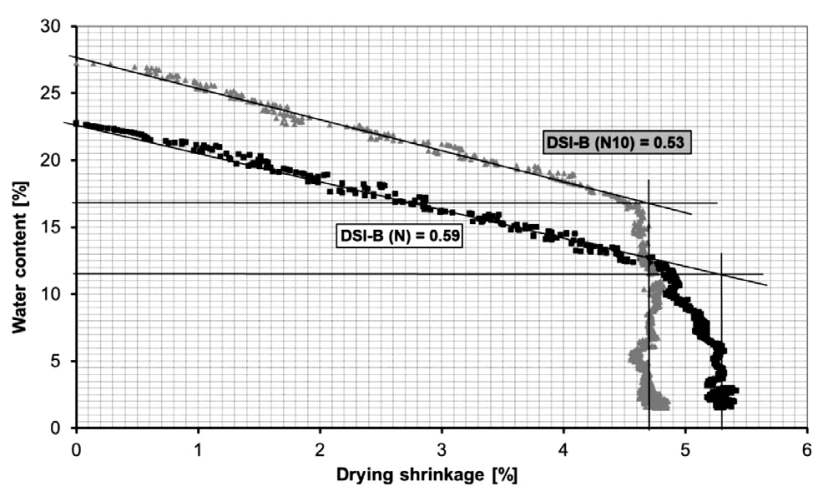

Figure 5: Relationship between drying shrinkage and water content (the Bigot curve) - DSI-B determination 
drying shrinkage $D S$, resulting in a reduction in the bulk density $B G$ of a dried green body (Table 4). The drying process of both compared plastic clay bodies (mixtures $\mathrm{N}$ and $\mathrm{N} 10$ ) is documented with the Bigot curve according to Bigot DSI-B, CCFA causes a complete decrease of the clay-body shrinkage when reaching the critical water content and a slight decrease in the sensitivity to drying (Figure 5).

Table 4: Properties of the plastic body ( $w_{\mathrm{r}}-$ water content, DS drying shrinkage, $B G$ - bulk density of a dried green body)

\begin{tabular}{|c|c|c|c|}
\hline Mixture & $w_{\mathrm{r}}(\%)$ & $D S(\%)$ & $B G\left(\mathrm{~kg} \cdot \mathrm{m}^{-3}\right)$ \\
\hline $\mathrm{N}$ & 22.7 & -5.3 & 1430 \\
\hline $\mathrm{N} 10$ & 27.0 & -4.7 & 1400 \\
\hline
\end{tabular}

According to Equation (3):

$$
2 \mathrm{CaSO}_{4} \rightarrow 2 \mathrm{CaO}+2 \mathrm{SO}_{2}+\mathrm{O}_{2}
$$

decomposition of anhydrite $\mathrm{CaSO}_{4}$ can be expected during the firing of a dry-pressed body based on pure CCFA when the temperature exceeds $1200{ }^{\circ} \mathrm{C}$ or about $1000{ }^{\circ} \mathrm{C}$ for dry-pressed clay/CCFA mixtures. ${ }^{17}$ For this reason, there is a risk of sulphur dioxide leakage during the firing of the N10 samples at higher temperatures, but this was not confirmed (Figure 6). Conversely, the admixture of CCFA resulted in a slight reduction of the $\mathrm{SO}_{2}$ content of the flue gas. This can be caused by the calcite content in CCFA, which was able to bind sulphur dioxide from the brick clay. The admixture of CCFA in brick clay slightly increases the shrinkage of the test samples during the firing (Figure 7) due to the sintering of body N10 in a range of $800-900{ }^{\circ} \mathrm{C}$ compared with body $\mathrm{N}$. We can observe a higher volume increase for the fired body, when CCFA is used (mixture N10), in a temperature range of about $1000-1100{ }^{\circ} \mathrm{C}-$ this is typical of an anorthite creation during the firing. ${ }^{18}$ CCFA is a source of a higher quantity of anorthite in the fired brick bodies due to the $\mathrm{CaO}$ content (Table 2).

The main effect of the CCFA addition to brick raw-material mixtures is in the pore-forming ability there is an evident bulk-density $(B)$ reduction and an

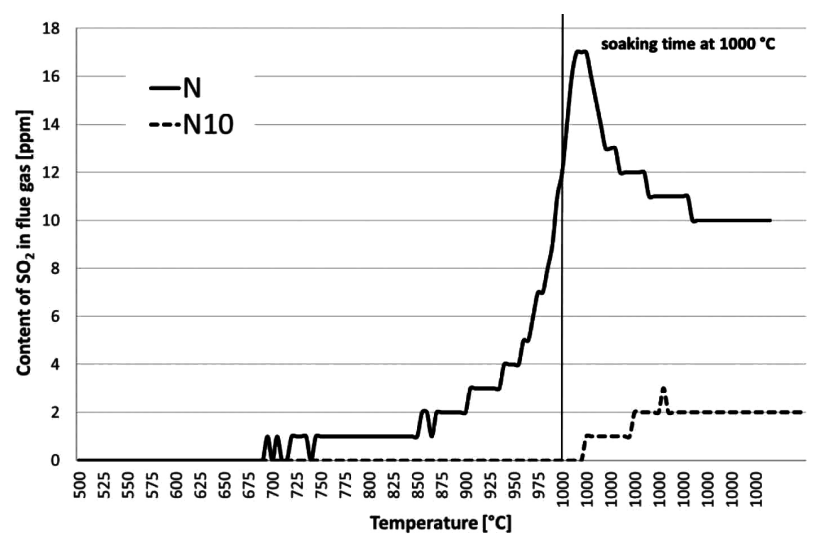

Figure 6: Content of sulphur dioxide $\left(\mathrm{SO}_{2}\right)$ in flue gas during the firing of test samples

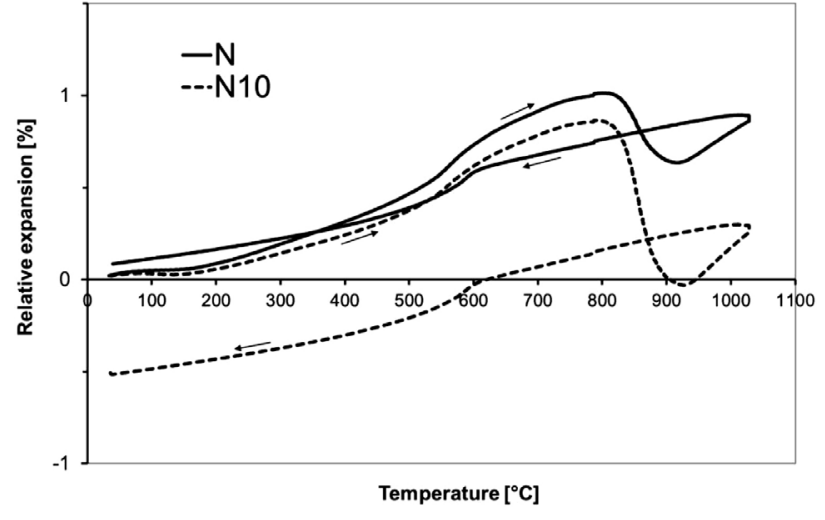

Figure 7: Dilatometric analysis during the firing $\left(3{ }^{\circ} \mathrm{C} / \mathrm{min}\right.$ without the soaking time)

increased water absorption (WA) of the body (Table 5) due to the decomposition of calcium carbonate and formation of anorthite, leading to a volume increase (Figure 7). Significantly better thermal-insulation properties of a fired brick body can be expected at both tested firing temperatures $\left(850{ }^{\circ} \mathrm{C}\right.$ and $\left.1000{ }^{\circ} \mathrm{C}\right)$ in the case of a CCFA addition to the raw-material mixture (N10) - see the coefficient of thermal conductivity, $\lambda$ in Table 5.

The efflorescence on the surface of brick specimens after a 7-day immersion in distilled water was documented. No marginal difference (N vs. N10) in the efflorescence was observed on the surface of the samples after drying at $110^{\circ} \mathrm{C}$ (Figure 8).

Table 5: Properties of fired bodies ( $R$ - flexural strength, $B$ - bulk density, $W A$ - water absorption, $F S$ - firing shrinkage) - the effect of the firing temperature

\begin{tabular}{|c|c|c|c|c|c|c|}
\hline Sample & $\begin{array}{c}\text { Firing } \\
\left({ }^{\circ} \mathrm{C}\right)\end{array}$ & $\begin{array}{c}R \\
(\mathrm{MPa})\end{array}$ & $\begin{array}{c}B \\
\left(\mathrm{~kg} \cdot \mathrm{m}^{-3}\right)\end{array}$ & $\begin{array}{c}W A \\
(\%)\end{array}$ & $\begin{array}{c}F S \\
(\%)\end{array}$ & $\begin{array}{c}\lambda \\
(\mathrm{W} / \mathrm{mK})\end{array}$ \\
\hline \multirow{2}{*}{$\mathrm{N}$} & 850 & 15.9 & 1720 & 23.0 & +1.5 & 0.5184 \\
\cline { 2 - 7 } & 1000 & 12.0 & 1700 & 28.3 & -0.1 & 0.6654 \\
\hline \multirow{2}{*}{$\mathrm{N} 10$} & 850 & 12.5 & 1590 & 22.9 & +0.3 & 0.4565 \\
\cline { 2 - 7 } & 1000 & 9.8 & 1560 & 28.0 & -0.6 & 0.4666 \\
\hline
\end{tabular}

\section{CONCLUSIONS}

In the Czech Republic, about 1.4 million tons of Class C fly ash (CCFA) are produced per year that are not applied in the production of building materials. The aim of the paper was to verify the applicability of CCFA

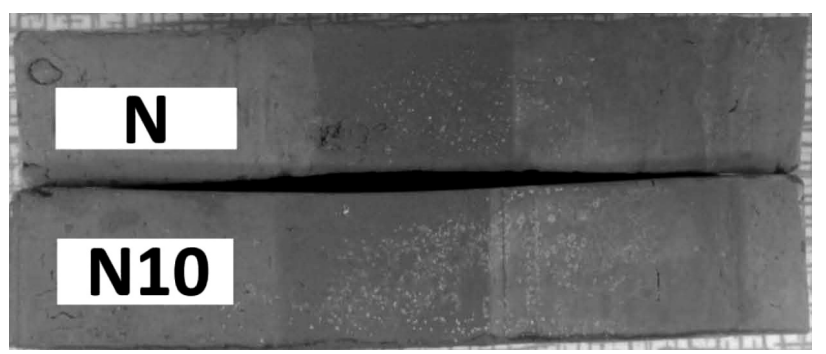

Figure 8: Fired samples after the efflorescence test 
in the brickmaking industry. A mixture of typical calcareous (about $12 \% / w /$ of calcite) brick clay for the production of clay masonry bricks (Novosedly, Wienerberger Group, Czech Republic) and $10 \% / w$ of CCFA (Tisova, CEZ Group, Czech Republic) was analysed and compared with a pure-clay brick. CCFA influences the properties of clay-body plasticity (increases the water content, decreases the drying shrinkage, drying sensitivity and bulk density of a green body) and a fired body (CCFA acts as a pore-forming agent - we can expect a lower bulk density and better thermal-insulation properties of fired bodies). Due to low firing temperatures in the brickmaking industry (in a range of $850-1000{ }^{\circ} \mathrm{C}$ ) there is no risk of an anhydrite decomposition - Class $\mathrm{C}$ fly ash does not increase the $\mathrm{SO}_{2}$ content in flue gas during the firing and efflorescence. As a source of $\mathrm{CaO}$, CCFA contributes to a higher anorthite content in a fired body.

\section{Acknowledgment}

This article was supported by the Czech Science Foundation GAČR, project No. 18-02815S with project name: Elimination of sulphur oxide emission during the firing of ceramic bodies based on fly ashes of Class $C$.

\section{REFERENCES}

${ }^{1}$ R. Sokolar, L. Smetanova, Dry pressed ceramic tiles based on fly ash-clay body: Influence of fly ash granulometry and pentasodium triphosphate addition, Ceramic International, 36 (2010) 1, 215-221

${ }^{2}$ I. Queralt, X. Querol, A. López-Soler, F. Plana, Use of coal fly ash for ceramics: a case study for a large Spanish power station, Fuel, 76 (1997) 87, 87-791

${ }^{3}$ M. Erol, A. Genç, M. L. Öveçolu, E. Yücelen, S. Küçükbayrak, Y. Taptik, Characterization of a glass-ceramic produced from thermal power plant fly ashes, Journal of the European Ceramic Society, 20 (2000) 12, 2209-2214

${ }^{4}$ L. Barbieri, I. Lancellotti, T. Manfredini, I. Queralt, J. Ma. Rincon, M. Romero, Design, obtainment and properties of glasses and glass-ceramics from coal fly ash, Fuel, 78 (1999) 2, 271-276
${ }^{5}$ M. Erol, S. Küçükbayrak, A. Ersoy-Meriçboyu, Characterization of sintered coal fly ashes, Fuel, 87 (2008) 7, 1334-1340

${ }^{6}$ M. Ilic, C. Cheeseman, C. Sollars, J. Knight, Mineralogy and microstructure of sintered lignite coal fly ash, Fuel, 82 (2003) 3, 331-336

${ }^{7}$ M. Erol, S. Küçükbayrak, A. Ersoy-Meriçboyu, Characterization of coal fly ash for possible utilization in glass production, Fuel, 86 (2007) 5-6, 706-714

${ }^{8}$ S. Abbas, M. A. Saleem, S. M. S.K. Kazmi, M. J. Munir, Production of sustainable clay bricks using waste fly ash: Mechanical and durability properties, Journal of Building Engineering, 14 (2017) 11, 7-14

${ }^{9}$ M. Sutcu, E. Erdogmus, O. Gencel, A. Gholampour, E. Atan, T. Ozbakkaloglu, Recycling of bottom ash and fly ash wastes in eco-friendly clay brick production, Journal of Cleaner Production, 233 (2019), 753-764

${ }^{10}$ E. Esmeray, M. Atis, Utilization of sewage sludge, oven slag and fly ash in clay brick production, Construction and Building Materials, 194 (2019) 1, 110-121

${ }^{11}$ Y. Deng, B. Gong, Y. Chao, T. Dong, W. Yang, M. Hong, X. Shi, G. Wang, Y. Jin, Z.-G. Chenc, Sustainable utilization of municipal solid waste incineration fly ash for ceramic bricks with eco-friendly biosafety, Materials Today Sustainability, 1-2 (2018) 11, 32-38

${ }^{12}$ C. Leiva, C. Arenas, B. Alonso-Fariñas, L. F. Vilchesa, B. Peceño, M. Rodriguez-Galán, F. Baena, Characteristics of fired bricks with co-combustion fly ashes, Journal of Building Engineering, 5 (2016) 3, 114-118

${ }^{13}$ K. Pimraska, M. Wilhelm, W. Wruss, A new approach to the production of bricks made of $100 \%$ fly ash, Tile and Brick Int., 16 (2000) 6, 428-433

${ }^{14}$ H. G. F. Winkler, Bedeutung der Korngrössenverteilung und des Mineralbestandes von Tonen feur die Herstellung grobkeramischer Erzeugnisse, Berichte der Deutschen Keramischen Gesellschaft, 31 (1954) 10, 337-343

${ }^{15}$ K. Pfefferkorn, Ein Beitrag zur Bestimmung der Plastizität in Tonen und Kaolinen, Sprechsaal, 57 (1924) 25, 297-299

${ }^{16}$ P. Aungatichart, S. Wada, Correlation between Bigot and Ratzenberger drying sensitivity indices of red clay from Ratchaburi province (Thailand), Applied Clay Science, 42 (2009) 2, 182-185

${ }^{17}$ R. Sokolar, M. Nguyen, The fly ash of class C for ceramic technology, $24^{\text {th }}$ Conference Construmat 2018, Herlany, Slovakia, IOP Conference Series: Materials Science and Engineering, 385 (2018) 1

${ }^{18}$ R. Sokolar, L. Vodova, S. Grygarova, I. Stubna, P. Sin, Mechanical Properties of Ceramics Bodies Based on Calcite Waste, Ceramics International, 38 (2012) 8, 6607-6612 